\title{
Occupational Safety and Health Behaviour of The Cleanliness Service Workers in Medan
}

\author{
Umi Salmah ${ }^{1}$, Arfah Mardiana Lubis², Isyatun \\ Mardhiyah Syahri ${ }^{3}$ \\ Department of Occupational Safety and Health \\ Faculty of Public Health USU, \\ usalmah73@yahoo.com, arfah@usu.ac.id, \\ iissyahri@gmail.com,
}

\author{
Yenny Obsi Satra ${ }^{4}$ \\ Faculty of Cultural Sciences \\ University of Sumatera Utara \\ Medan, Indonesia \\ yennysatra26@yahoo.com
}

\begin{abstract}
Human factor occupies a very important position against the occurrence of work accidents that is between $80-85 \%$. Health Safety and Environment Accident Prevention Unit said that $90 \%$ of the accidents were caused by human errors and $70 \%$ of them can be prevented. The accident prevention effort in Indonesia faces so many problems such as traditional mindset which assumes an accident as a disaster so that the people would be surrender. The occupational unsafe acts were caused by some reasons such as the inadequate knowledge by the workers about occupational safety and health (OHS). The inadequate knowledge on potential hazards and risks of accidents will make workers ignoring the safety in working that affects their safety. This research was aimed at knowing the relationship between the knowledge on OHS with the safe Acts in working on cleanlines service workers in Medan. Analytical research was done with the population of 815 people of Melati group criterion, on set workers who work for $\geq 1$ year and sample of 260 workers in 21 sub-districts in Medan which are taken randomly by questionairres. The data analysis in this research used univariat analysis and bivariate with Chi-Square test. As the result of the analysis, there are 163 workers $\leq 48$ years old $(62.7 \%), 135$ workers with primary school education background, and 200 workers with working period $\leq 22$ years $(76.9 \%)$. There are 254 workers who get adequate knowledge on OHS (97.7\%) and 121 workers who do occupational safe acts $(46.5 \%)$. From the statistic test, the researcher gets $p=0.08(<0,05)$, interpreted as there is a relationship between having OHS knowledge and the occupational safe acts on cleanlines service workers in Medan. It is suggested for Sanitation Departmentof Medan as a leading sector to more improve the controlling effort due to the adequate knowledge of the workers but there are some who ignoring the occupational safe acts.
\end{abstract}

Keywords - Behaviour; Occupational safety and health; Cleanlines Service Workers

\section{INTRODUCTION}

Accidents are caused by two factors. The first factor is mechanic and environment factor which involves all things except human. The second one is the human themselves [1]. Several studies have shown that the human factor occupies a very important position against the occurrence of occupational accidents that is between $80-85 \%$. This means that insecure employment is the biggest cause of occupational accidents. Unsafe action is a dangerous act of the workers which may be happened by various reasons, and one of them is less knowledge [2].

The accident prevention effort in Indonesia is still facing so many problems such as traditional mindset, which assumes the accident as a disaster, so the people would be surrender [3]. They are surrendering in facing the reality and there is no effort to prevent the accidents. Performing unsafe acts may be due to lack of workers' knowledge on occupational safety and health. Inadequate knowledge of the potential hazards and risks of accidents will make the workers neglects and acts unsafely which affects their safety.

The Health Safety and Environment (HSE) of the Accident Prevention Unit says that $90 \%$ of accidents are caused by human error and $70 \%$ can be avoided / prevented by the initial action from the management [4]. By law, every leader / employer has a "general duty" to provide a workplace that is "free from known hazards" [5]. The employer / leader should provide periodic information on the health and physical hazards associated with office materials and products to all of theiremployees [6].

Based on the results of a preliminary survey conducted in the field on road sweepers in Medan, it seemed that the workers sweep without looking at the vehicles behind them,between the right and left lanes, alongside the sidewalk and some were not using Personal Protective Equipment such as masks, gloves and safety shoes . Based on the research conducted by Salmah and Lubis, 2016 on 20 informants interviewed; it was identified that there were 3 safety hazards that are: hit by a vehicle, beaten by a madman and punctured by a sharp object.

Hazards always come in every work situation, how much of this danger and whether it can increase and keep a hazard control [7]?. The purpose of K3 is to avoid injury, pain, and death5. The challenge in applying $\mathrm{k} 3$ on the field is how to create and keep the interest of the workers towards K3 [8]. The learning process is successful when the individual gets more knowledge, change their perceptions, behaviors and 
responds with different ways from the previous individual's behavior [9]. Accidents do not happen accidentally. Because it should be investigated and discovered in order to take further corrective action and by the preventive efforts, accidents can be prevented so the same accidents would not happen again in the future.

Occupational safety and health contains of protecting the workers from the accidents or occupational diseases [11]. The purpose of this research is to know $\mathrm{K} 3$ behavior in cleanliness workers in Medan.

\section{MATERIALS AND METHODS}

This research is an analytic research which aims to know the behavior of K3 oncleanliness service workers in Medan. This research was conducted by using cross sectional research design. The population is the workers of cleanliness service workers in Medan consist of 21 Districts of 815 people and the sample is taken from 260 people. The collection of sample members from the population is done randomly regardless of the strata in the population [12]. Data analysis used in this research isUnivariatAnalysis, that is an analysis to get the description of distribution and frequency of each research variable followed by Bivariat analysis, that is further analysis used to know the influence of the knowledge variable to the dependent variable of safe acts in working using Chi-Square Analysis.

\section{RESULTS}

\section{Univariate Analysis}

Univariate analysis is used to see the frequency of distribution of characteristic variable, independent variable that is knowledge and dependent variable Safe Acts in working.

TABLE I. DISTRIBUTION OF AGE FREQUENCY, LEVEL OF EDUCATION, WORKING PERIOD, KNOWLEDGE AND SAFE ACTION AT HYGIENE SERVICES WORKER IN MEDAN CITY 2017

\begin{tabular}{|c|c|c|}
\hline Age (Year) & Frequency (n) & $\begin{array}{c}\text { Persentage } \\
(\mathbf{\%})\end{array}$ \\
\hline$\leq 48$ & 163 & 62,7 \\
\hline$>48$ & 97 & 37,3 \\
\hline Total & 260 & 100 \\
\hline $\begin{array}{c}\text { Education } \\
\text { Background }\end{array}$ & Frequency (n) & $\begin{array}{c}\text { Persentage } \\
(\mathbf{\%})\end{array}$ \\
\hline SD & 135 & 51,9 \\
\hline SMP & 61 & 23,5 \\
\hline SMA/Equal & 62 & 23,8 \\
\hline College & 2 & 8,0 \\
\hline Total & 260 & 100 \\
\hline $\begin{array}{c}\text { Working Period } \\
\text { (Year) }\end{array}$ & Frequency (n) & $\begin{array}{c}\text { Persentage } \\
(\boldsymbol{\%})\end{array}$ \\
\hline$\leq 22$ & 200 & 76,9 \\
\hline$>22$ & 60 & 23,1 \\
\hline Total & 260 & 100 \\
\hline
\end{tabular}

\begin{tabular}{|c|c|c|}
\hline Knowledge & Frequency (n) & $\begin{array}{c}\text { Persentage } \\
(\mathbf{\%})\end{array}$ \\
\hline Know & 254 & 97,7 \\
\hline Doesn't Know & 6 & 2,3 \\
\hline Total & 260 & 100 \\
\hline Unsafe Acts & Frequency (n) & $\begin{array}{c}\text { Persentage } \\
(\boldsymbol{\%})\end{array}$ \\
\hline NO & 139 & 53,5 \\
\hline YES & 121 & 46,5 \\
\hline Total & 260 & 100 \\
\hline
\end{tabular}

From the table above, we obtained as follows:there are 163 workers $\leq 48$ years old $(62.7 \%)$, and 97 workers $>48$ years old $(37.3 \%)$. There are 135 workers with primary school education background(51,9\%), 61 workersof junior high school background(23,5\%), 62 workers of senior high schollbackround(23,8\%), and 2 workers with college background $(8,0 \%)$. There are also 200 workers with working period $\leq 22$ years $(76.9 \%)$ and 60 workers with $>22$ years of working period $(23.1 \%)$. There are 254 workers who get adequate knowledge on OHS (97.7\%)and 6 workers who do not get adequate knowledge on OHS (2.3\%).There are 139 respondents who said NO to the safe acts $(53.5 \%)$, and 121 respondents who said YES (46.5\%).

\section{Bivariate Analysis}

Bivariate analysis is conducted to find out the relationship between independent variable Knowledge with dependent variable (Safe Acts). Hypothesis testing is done by using Chi Square Test.

TABLE II. RELATIONSHIP BETWEEN KNOWLEDGE WITH SAFE ACTS AT HYGIENE SERVICES WORKER IN MEDAN CITY 2017

\begin{tabular}{|c|c|c|c|c|c|c|c|}
\hline \multirow{2}{*}{ Knowledge } & \multicolumn{6}{|c|}{ Safe Acts } \\
\cline { 2 - 8 } & \multicolumn{2}{|c|}{ NO } & \multicolumn{2}{c|}{ YES } & \multicolumn{2}{c|}{ Total } & P \\
\cline { 2 - 7 } & $\mathbf{n}$ & $\%$ & N & $\%$ & n & $\%$ & value \\
\hline Know & 139 & 53,5 & 115 & 44,2 & 254 & 97.7 & .008 \\
\hline Doesn't Know & 0 & 0 & 6 & 2,3 & 6 & 2.3 & \\
\hline Total & 139 & 53,5 & 121 & 46.5 & 260 & 100 & \\
\hline
\end{tabular}

Based on the results, there are 115 workers who know about $\mathrm{k} 3$ and perform safe acts $(44.2 \%)$. The statistical test results between knowledge with safe action is known that $\mathrm{p}=$ $.008(<0.05)$, so it can be interpreted that there is a relationship between knowledge with safe action in working of thecleanlines service workers in Medan.

\section{DISCUSSION}

1. Age

The age of the respondents in this study was categorized based on median value to $\leq 48$ years and $>48$ years. Based on the results of the study, it can be seen that there are 163 respondents $\leq 48$ years old and 97 respondents $>48$ years old. This shows that the percentage of the two age groups is not great. From the data it is clear that there is no meaningful 
difference in the case of respondents who are $\leq 48$ years old who do unsafe acts with respondents aged $>48$ who perform unsafe acts.

It is seen from the results of this study that the actual workers who are adult have no longer possibility to change their work. Workers feel that it is common for them not to use masks and gloves because they feel they are rarely sick and keep healthy. The same thing is said by some experts that concluded that young employees at the most dissatisfied tend to quit their jobs or change jobs and many older employees have a greater chance of achieving self-actualization in their work [13]. Based on the authors' assumption, that most of the street sweepers of late adultsfeel that the work accident is common in working. The experience of vigilance against accidents improves by the age [14].

\section{Education}

Respondent's education background in this study is categorized based on education level of elementary, junior high school, senior high school / equivalent and college / university. Based on the results of the research, it can be seen that there are 135 workers $(51.9 \%)$ who have elementary education, 61 workers withjunior high school background( $23.5 \%), 62$ workers with high school or equivalent background(23.8\%) and 2 workers with college / University background as much as 2 people $(8 \%)$. The results of this study indicate that the education of those respondents is quite low, because many are elementaryeducated. The low level of education is usually very significant with low knowledge especially on the risks in the work environment. The low education and knowledge of workers will also automatically affect their actions in the workplace. Workers are difficult to understand following the work procedure as an effort to prevent accidents. Information to use PPE is very important but some of them just say it makes them uncomfortable. Garbage is a kind of disease and when weremove the waste, we should use anyequipment and APD to avoid germs that cause diseases such as worms, some of them say that they are old and will not experience wormy.

\section{Working Period}

The working period is a period or length of workforce working in a workplace. The period of work can basically have a positive or negative effect on the workers. It brings positive influence if the longer work givesmore experiences and understanding of workplace conditions in carrying out their duties and vice versa andit gives a negative effect if along with the longer work, a person makes some negative habits in the workplace. The period of work is related to the length of work of the road sweepers in their workplace. Based on the results of the research, it can be seen that 200 workers $(76.9 \%)$ who have a working period of $\underline{2} 2$ years, and 60 workers $(23.1 \%)$ who works for $>22$ years. The working period of those who perform safe acts and cause fatalworkplace accidents are usually not found because if they experience a fatal accident they usually will stop working. Those who perform unsafe acts in the ne work periodwill not fully understand the conditions of the workplace. Work experience is a factor associated with OSH conditions.

\section{Knowledge andThe Unsafe Acts}

Knowledge of the respondents in this research is categorized based on median value that is: know and do not know. The results of the study found the respondents who know about how to prevent accidents while working,understand the safe position while working, understand that the wrong work attitude can cause musculoskeletal complaints, understand that collecting garbage must use equipment / not using hands without gloves, know that garbage can cause various diseases and the respondentsapply the safe acts in work.

In this study there is a significant relationship between knowledge factors and the safe acts in work, which means that the need for continuous improvement of work knowledge by ensuring workers to recognize the needs of their work. It can be concluded that each worker will be more familiar with the needs of the job because of a system to monitor their efforts to apply K3. Besides, the experience and knowledge of the worker are also one of the resources in the process of integrating K3 [8].

It finds $p=.008(<0.05)$, so it can be interpreted that there is a significant relationship between knowledge and safe acts on cleanliness service in Medan. And if we see the results of research, most of respondents do not know any work procedures especially textually. It is very important to demonstrate and explain the operational standard of this work procedure to the worker because by explaining and looking at them, they will be more aware of it and will act safely. At the time of transferring the knowledge, it is strongly influenced by the intensity of attention perception of the object. Much of human knowledge is obtained through the eyes and ears [15].

\section{CONCLUSIONS AND SUGGESTIONS}

\section{Conclusions}

Of the 260 respondents, there are 254 workers who answered well about k3 (97.7\%), and 6 workers who did not knowwell about k3 (2.3\%). There are 139 workers who answered NO to the safe acts $(53.5 \%)$, and 121 workers who answered YES (46.5\%). There are 115 workers who know about $\mathrm{k} 3$ and perform safe acts $(44.2 \%)$. There is a relationship between knowledge with safe action in working on cleanliness service in Medan.

\section{Suggestions}

It needs SMK3 policy to evaluate behavior in work by considering knowledge. It is expected that the workers will 
give priority to their safety while working by increasing their knowledge and discourse on $\mathrm{K} 3$.

\section{ACKNOWLEDGEMENT}

The authors would like to thank to University of Sumatra Utara for the support which has funded this research through research programs of BidangUnggulanAkademik USU Year 2017. Many thanks also goto the Medan Research and Development Department, Sanitation Department of Medan Government and all cleanliness Services workers as the respondents in this research.

\section{REFERENCES}

[1] Peraturan Walikota Medan No.14 Tahun 2014. Tentang pembentukan unit pelaksana teknis pelayanan kebersihan dan unit pelaksana teknis bank sampah Pada Dinas Kebersihan: Kota Medan.

[2] UU Republik Indonesia No.1 tahun 1970. Tentang Keselamatan Kerja. Jakarta: Kementrian TenagaKerja.

[3] Cresswell J W. Research Design Pendekatan Kualitatif, Kuantitatif dan Mixed. Yogyakarta: 2014.
[4] Pill Hughes, F. E. (2009). Introduction Health And Safety at Work: Slovenia.

[5] Cascio, W. F. (2014). Managing Human Resources, (Tenth ed.). New york: Mc.Growhill Education.

[6] Reese, C. D. (2009). Industrial Safety and Health for Administrative Services. USA: CRC Press

[7] John Ridleydan Channing, J. Safety At Work. USA: Elsevier; 2008.

[8] Somad I. Tekhnik Efektif Dalam Membudayakan Keselamatan \& Kesehatan Kerja. Jakarta : PT Dian Rakyat; 2013.

[9] Kurniawidjaja.L.M. Teori Dan Aplikasi Kesehatan Kerja. Jakarta: UI Press; 2012.

[10] Suma'mur. Higiene Perusahaan dan Kesehatan Kerja (Hiperkes). Jakarta: SagungSeto; 2009.

[11] Ramli S. Sistem Manajemen Keselamatan dan Kesehatan Kerja OHSAS 18001, Edisi Ketiga. Jakarta : Dian Agung; 2013.

[12] Sugiyono. Metode Penelitian Bisnis (Pendekatan Kuantitatif, kualitatif, dan R\&D).Bandung: CV Alfabeta; 2012.

[13] Wijono, S. Psikologi Industri dan Organisasi Jakarta: Kencana; 2010.

[14] Suma'mur. Higiene Perusahaan dan Kesehatan Kerja (Hiperkes). Jakarta: Gunung Agung; 1996.

[15] Wawan, A Dan Dewi. Teori \& Pengukuran Pengetahuan, Sikap dan perilaku Manusia. Yogyakarta: Muha Medika; 2010. 